\title{
Heart failure with preserved systolic function: prevalence and clinical features in a cohort of patients admitted to internal medicine units. The study PRESYF-HF Tuscany
}

\section{Scompenso cardiaco con funzione sistolica conservata: prevalenza e presentazione clinica in una coorte di pazienti ricoverati in reparti di medicina interna. Lo studio PRESYF-HF Toscana}

\author{
Paolo Biagi1, Luigi Abate1, Massimo Alessandri2, Salvatore Bocchini1, \\ Valerio Verdiani3, Giuseppe Pettinà ${ }^{4}$, Carlo Nozzoli3
}

\begin{abstract}
Heart failure with preserved systolic function: prevalence and clinical features in a cohort of patients admitted to internal medicine units. The study PRESYF-HF Tuscany. P. Biagi, L. Abate, M. Alessandri, S. Bocchini, V. Verdiani, G. Pettinà, C. Nozzoli.

Background. There is uncertainty about the prevalence and clinical characteristics of heart failure (HF) patients with preserved systolic function (PRESYF).

Aim. To analyze the prevalence and clinical characteristics of patients with PRESYF in an unselected cohort of subjects consecutively hospitalized for HF.

Methods. The study cohort included 338 patients consecutively admitted for HF at 24 Internal Medicine units homogeneously settled in Tuscany area (Italy). We did not have any criteria for exclusion. All patients had an echocardiographic measure of left ventricular ejection fraction
\end{abstract}

(LVEF) within 72 hours from hospital admission. Patients with LVEF $\geq 50 \%$ were considered to have PRESYF.

Results. The patients with PRESYF were $112(33,1 \%)$, those with depressed systolic function (DESYF) $226(66,9 \%)$. In the group PRESYF were prevalent female sex, hypertensive etiology, and elevated BMI. The distribution for classes of age shows a great frequency of PRESYF in the elderly.

Conclusion. About one third of patients admitted for HF have a PRESYF. They are different compared to those with DESYF. A correct identification of this form of $\mathrm{HF}$ may be important in clinical practice for more targeted therapeutic options and for prognostic implications.

Keywords: heart failure, preserved left ventricular ejection fraction, prevalence, clinical features.

Monaldi Arch Chest Dis 2007; 68: 165-169.

\footnotetext{
1 Internal Medicine, Ospedali Riuniti Valdichiana, Montepulciano (SI), Italy.

2 Internal Medicine, Ospedale della Misericordia, Grosseto, Italy.

3 Internal Medicine 1, Azienda Ospedaliera Universitaria Careggi, Florence, Italy.

4 Internal Medicine, Ospedale del Ceppo, Pistoia, Italy.
}

Corresponding author: Dr. Valerio Verdiani; Via A. Faccioli N 15, I-50145 Florence, Italy; E-mail address: verdiani@fastwebnet.it

\section{Introduction}

Heart failure (HF) with preserved systolic function (PRESYF) is a growing remarkable clinical problem $[1,2]$. This condition is generally considered to be primarily due to diastolic dysfunction [3]. The most accurate evaluation of the diastole is obtainable through cardiac catheterism $[4,5]$, but it is not routinely employed in clinical setting for practical reasons (invasive method, not available in all hospitals). Although Doppler echocardiography is a widely accepted tool for identifying left ventricular ejection fraction (LVEF) [6-10] a non-invasive gold standard for assessing left ventricular diastolic function does not exist [3].

Controversy exists on many key elements of this entity, including prevalence and clinical characteristics. In a recent metanalysis, its prevalence ranged between 13 to $74 \%$ [11]. That was primarily due to difference in the populations studied and the definition of PRESYF.

In the past, only few studies have been conducted in unselected populations [12,13], and the definition of preserved LVEF ranged from $\geq 40 \%$ to $\geq 55 \%$ [3].
Recently, it has been underlined that PRESYF is defined as LVEF greater than or equal to $50 \%$ and to date this is the most widely accepted cut off $[14,15]$.

Furthermore, the timing of echo examination (within 72 hours from admission) seems important for the proper definition of HF with preserved LVEF $[16,17]$.

The aim of our study was to analyze the prevalence and clinical characteristics of patients with PRESYF in an unselected cohort of subjects consecutively hospitalized for symptoms of HF in Internal Medicine Units of Tuscany, a region of central Italy.

\section{Methods}

The study cohort included 338 patients consecutively admitted at 24 Internal Medicine units homogeneously settled in Tuscany area (Italy).

Criteria for inclusion were exacerbation of previously documented HF or new onset of HF using standard Framingham criteria [18]. We did not have any criteria for exclusion. 
All patients had an echocardiographic measure of LVEF within 72 hours from hospital admission, and performed according to guidelines of the European Society of Cardiology [19]. Patients with clinical diagnosis of $\mathrm{HF}$ and $\mathrm{LVEF} \geq 50 \%$ measured with Simpson method [20] were considered to have PRESYF HF. Demographic features, clinical and laboratory data were also recorded.

\subsection{Statisical analysis}

Data are presented as mean \pm 1 standard deviation (SD) or absolute number or percentages. Statistic analysis has been effected applying the chi-square test or Fisher test when appropriate. After testing data for normality (Kolmogorov-Smirnov test associated to the index of Lilliefors), analysis of variance (ANOVA) has been applied and a $\mathrm{p}$ value $<0.05$ was considered statistically significant. Statistic analysis has been performed with "Epi Info 6.0" by the Centers for Disease Control and Prevention (CDC) and with "Statistica", version 6.0, by the StatSoft Inc. (2001).

\section{Results}

Of the 40 Internal Medicine units of Tuscany, 24 $(60 \%)$ have participated in the study. Their regional distribution was homogeneous (Figure 1).

The cohort of patients consecutively admitted with $\mathrm{HF}$ included 338 subjects, mean age $81 \pm 9 \mathrm{yrs}$, males $156(46,2 \%)$, females $182(53,8 \%)$.

The patients with PRESYF (LVEF $\geq 50 \%$ ) were $112(33,1 \%)$, those with depressed systolic function (DESYF) (LVEF <50\%) $226(66,9 \%)$.

In the group PRESYF were prevalent female sex, hypertensive etiology, and elevated body mass index (BMI) (Table 1).

Table 1. - Characteristics and clinical and laboratory data of the population and comparison between patient with preserved systolic function - heart failure (PRESYF-HF) and depressed systolic function - heart failure (DESYF-HF) - in parenthesis the number of the cases

\begin{tabular}{|c|c|c|c|c|}
\hline & Overall & DESYF $($ LVEF < 50\%) & PRESYF $($ LVEF $\geq 50 \%)$ & $P$ value \\
\hline Number of Cases & 338 & $226(66.9 \%)$ & $112(33.1 \%)$ & \\
\hline Age & $81.9 \pm 7.8$ & $80.8 \pm 7.1$ & $81.3 \pm 9.1$ & NS \\
\hline Male & $156(46.2 \%)$ & $53.1 \%$ & $31.3 \%$ & 0.002 \\
\hline \multicolumn{5}{|l|}{ Etiology } \\
\hline Ischemic & $178(52.7 \%)$ & $148(65.4 \%)$ & $30(26.8 \%)$ & $\mathrm{P}<0.001$ \\
\hline Hypertensive & $146(43.2 \%)$ & $84(37.2 \%)$ & $62(55.4 \%)$ & $\mathrm{P}<0.001$ \\
\hline Valvular & $57(16.9 \%)$ & $37(16.4 \%)$ & $20(17.9 \%)$ & $\mathrm{P}<0.001$ \\
\hline Idiopathic & $12(3.6 \%)$ & $8(3.5 \%)$ & $4(3.6 \%)$ & NS \\
\hline Atrial Fibrillation & $134(39.6 \%)$ & $89(39.3 \%)$ & $45(40.2 \%)$ & NS \\
\hline \multicolumn{5}{|l|}{ Comorbidities } \\
\hline Diabetes & $94(27.8 \%)$ & $60(26.6 \%)$ & $34(30.4 \%)$ & NS \\
\hline Chronic renal failure & $33(9.8 \%)$ & $25(11.1 \%)$ & $8(7.1 \%)$ & NS \\
\hline Hypertension & $135(39.9 \%)$ & $81(35.8 \%)$ & $54(48.2 \%)$ & $\mathrm{P}<0.001$ \\
\hline Depression & $33(9.8 \%)$ & $22(9.7 \%)$ & $11(9.8 \%)$ & NS \\
\hline \multicolumn{5}{|c|}{ Laboratory data } \\
\hline BMI & (205) $25.8 \pm 5.0$ & (141) $24.9 \pm 3.7$ & (64) $27.6 \pm 6.6$ & $\mathrm{P}<0.001$ \\
\hline Heart rate(beats/min) & (327) $93.4 \pm 22.7$ & (118) $95.1 \pm 22.7$ & (109) $90.0 \pm 22.5$ & NS \\
\hline Atrial Fibrillation & $134(39.6 \%)$ & $89(39.3 \%)$ & $45(40.2 \%)$ & NS \\
\hline Systolic Blood pressure (mmHg) & $(335) 142.0 \pm 27.8$ & (223) $139.0 \pm 27.9$ & (112) $148.2 \pm 26.7$ & $\mathrm{P}<0.01$ \\
\hline Creatinine $(\mathrm{mg} \%)$. & (332) $1.4 \pm 0.9$ & (221) $1.5 \pm 1.0$ & (111) $1.3 \pm 0.7$ & $\mathrm{P}<0.05$ \\
\hline Creatinine $>2,5 \mathrm{mg} \%$ & $29(8.6 \%)$ & $23(10.2 \%)$ & $6(5.4 \%)$ & NS \\
\hline Hemoglobin $(\mathrm{g} / \mathrm{dL})$ & (338) $12.3 \pm 2.0$ & (226) $12.4 \pm 2.0$ & (112) $12.1 \pm 2.1$ & NS \\
\hline$\underline{\mathrm{Na}^{+}(\mathrm{mEq} / \mathrm{L})}$ & (338) $138.6 \pm 5.1$ & (226) $138.3 \pm 5.5$ & (112) $139.2 \pm 4.2$ & NS \\
\hline BNP (microU/ml) & (22) $840.0 \pm 810.4$ & (10) $1112.9 \pm 901.1$ & (12) $512.4 \pm 566.9$ & NS \\
\hline NTproBNP (microU/ml) & (32) $10304.6 \pm 14870.6$ & (28) $10901.6 \pm 15711.3$ & (4) $6125.3 \pm 6069.5$ & NS \\
\hline Ca125 (microU/ml) & (89) $82.6 \pm 114.0$ & (59) $89.7 \pm 127.7$ & (30) $68.7 \pm 80.5$ & NS \\
\hline
\end{tabular}


The distribution for classes of age shows a great frequency of PRESYF in the elderly (Table 2).

Among the causes of in hospital admission hypertensive crisis and atrial fibrillation were more frequent in PRESYF HF than in DESYF HF subjects (Table 3 ).

The number of HF patients with New York Heart Association (NYHA) classes III-IV was greater in the DESYF group both at admission and at hospital discharge, while we did not find any difference about lenght of hospital staying and intrahospital mortality (Table 4).

\section{Discussion}

In our cohort of unselected consecutive HF patients, the prevalence of PRESYF HF is $33,1 \%$.

Retrospective hospital based studies have shown a prevalence ranging from 40 to $53 \%$. The reasons for such difference may be due to differences in age

Table 2. Distribution of the population in three classes of age. The differences are not statistically significant

\begin{tabular}{lccc}
\hline \multirow{2}{*}{$\begin{array}{l}\text { Years Age } \\
\text { Classes }\end{array}$} & \multicolumn{3}{c}{ Number of Patients (\%) } \\
\cline { 2 - 4 } & $\begin{array}{c}\text { All } \\
\mathbf{( 3 3 8 )}\end{array}$ & $\begin{array}{c}\text { LVF<50\% } \\
(\mathbf{2 2 6})\end{array}$ & $\begin{array}{c}\text { LVEF }>\mathbf{5 0 \%} \\
(\mathbf{1 1 2})\end{array}$ \\
\hline$<60$ & $9(2,7 \%)$ & $5(2,2 \%)$ & $4(3,6 \%)$ \\
\hline $61-80$ & $127(37,5 \%)$ & $91(40,2 \%)$ & $36(32,1 \%)$ \\
\hline$>80$ & $202(59,7 \%)$ & $130(57,5 \%)$ & $72(64,2 \%)$ \\
\hline
\end{tabular}

Table 3. - Causes of admission

\begin{tabular}{lccc}
\hline Cause of admission & $\begin{array}{c}\text { LVEF } \\
\mathbf{N}^{\circ} \text { of cases }\end{array}$ & $\begin{array}{c}\text { LVEF }>\mathbf{5 0 \%} \\
\mathbf{N}^{\circ} \text { of cases }\end{array}$ & $\begin{array}{c}\text { P } \\
\text { value }\end{array}$ \\
\hline Progressive worsening * & $179(53 \%)$ & $56(50 \%)$ & NS \\
\hline Hypertensive crisis $\S$ & $44(13 \%)$ & $29(26 \%)$ & $<0.05$ \\
\hline Atrial fibrillation & $27(8 \%)$ & $21(19 \%)$ & $<0.05$ \\
\hline Infection & $30(9 \%)$ & $15(13 \%)$ & NS \\
\hline Low compliance & $20(6 \%)$ & $12(11 \%)$ & NS \\
\hline Anemia & $24(7 \%)$ & $6(5 \%)$ & NS \\
\hline Myocardial infarction & $7(2 \%)$ & $3(3 \%)$ & NS \\
\hline Tyreotoxicosis & $3(1 \%)$ & $2(2 \%)$ & NS \\
\hline Emotionall Stress & $7(2 \%)$ & $2(2 \%)$ & NS \\
\hline Pulmonary embolism & $3(1 \%)$ & $1(1 \%)$ & NS \\
\hline Not defined & $41(12 \%)$ & $13(12 \%)$ & NS \\
\hline
\end{tabular}

(*) The term progressive "worsening" points out the progressive worsening of HF irrespective of the etiology and not induced by any evident recognizable cause which altered a relatively stable disease.

(§) Hypertensive crisis means any increase of systolic blood pressure above $179 \mathrm{mmHg}$ and/or any increase of systodiastolic blood pressure above 179/110 $\mathrm{mmHg}$.
Table 4. - Frequency of the most compromised heart failure (HF) functional classes at entry and of the less severe at discharge from hospital, mean lenght of stay (+1 SD) and mortality. Length in hospital staying of the patients with preserved systolic function-heart failure (PRESYF-HF) and depressed systolic function - heart failure (DESYF-HF)

\begin{tabular}{lccc}
\hline NYHA Class & $\begin{array}{c}\text { LVEF } \geq \mathbf{5 0 \%} \\
\mathbf{N}^{\circ} \text { of cases }\end{array}$ & $\begin{array}{c}\text { LVEF }<\mathbf{5 0 \%} \\
\mathbf{N}^{\circ} \text { of cases }\end{array}$ & $\begin{array}{c}\mathbf{P} \\
\text { value }\end{array}$ \\
\hline $\begin{array}{l}\text { III-IV class } \\
\text { at admission }\end{array}$ & $83(74 \%)$ & $202(90 \%)$ & $\mathrm{P}<0.05$ \\
\hline $\begin{array}{l}\text { I-II classe } \\
\text { at discharge }\end{array}$ & $85(75 \%)$ & $134(59 \%)$ & $\mathrm{P}<0.05$ \\
\hline mortality & $3(2.6 \%)$ & $9(4 \%)$ & n.s. \\
\hline \multicolumn{4}{c}{ Lenght of stay } \\
(days \pm SD) & $8.82+5.18$ & $8.60+5.65$ & n.s. \\
\hline
\end{tabular}

[21, 22], gender [23-25], or race [26]; in other cases methods for measuring ventricular dysfunction [6, 7] or a lower threshold for LVEF (> 40\%) [13, 2729] may account for different results. Furthermore, the time of execution of the echo is reported in few studies.

In a perspective analysis of about one decade of patients admitted to a HF Clinic the echo performed within 2 weeks from the entry, has individualized a prevalence of almost $40 \%$ [30].

In a cohort study [31] on 328 patients admitted in the hospital with HF (Framingham criteria) with echo effected within 48 hours, the prevalence of PRESYF has been of $41,5 \%$, individualizing a predominantly female population and slightly more elderly in comparison to the subjects with LVEF $<40 \%$. However, that cohort was younger than our population (65 yrs of average) and also included patients with modestly DESYF (LVEF $\geq 40 \%$ ).

In another perspective study echo was performed within 72 hours from admission in over $70 \%$ of patients and the prevalence of PRESYF was 48\%, identifying a population of elderly, hypertensive with several comorbidities and showing a trend to a precocious re-hospitalization; however also in that population the cut off value for preserved LVEF was $>40 \%$ [32].

Although the timing of the echo seems not to modify the prevalence of the PRESYF induced by hypertensive HF [17] it is not clear if the same can be said for the forms induced by ischemic cause. It is reasonable to suppose that $\mathrm{HF}$ induced by ischemic heart disease may have a depressed ventricular function during and immediately after the event. We argue that if the echo is performed early after the admission we might measure the real burden of the PRESYF HF phenomenon irrespective of the etiology. Therefore, in our study, echocardiogram was performed within 72 hours from the admission in all patients, included those with ischemic heart disease (who represented about $30 \%$ of the whole cohort).

The demographic characteristics of our cohort are similar to data of observational studies performed in the same setting and territory $[33,34]$. Patients were 
those consecutively admitted for HF, without any criterium of exclusion. They could be so considered very representative of the "real world" of $\operatorname{HF}[27,35,36]$.

In our study, subjects with PRESYF HF are prevalently female, and older than patients with DESYF HF (age $>80$ years in $64,2 \%$ vs. $57,5 \%$ ). These characteristics are consistent with results of a study on a community cohort in Olmsted County, Minnesota [15], where HF with preserved LVEF had a prevalence of $55 \%$ and was associated with older age, female sex, and no history of myocardial infarction. The higher prevalence may be due to the fact that the population study included outpatients.

In our cohort, hypertensive heart disease is prevalent in patients with PRESYF HF $(54,1 \%$ vs $37,4 ; \mathrm{p}<0,001)$ and systolic blood pressure (SBP) values were significantly higher in this group. On the contrary, the ischemic heart disease prevails in the DESYF HF $(65,3 \%$ vs $27,5 \%$; p <0,001). Body mass index (BMI) was higher in the PRESYF HF subjects, consistently with published data [42, 43], while comorbidity was similar in patients with $\mathrm{HF}$ and preserved or reduced LVEF, as elsewhere reported [15, 32, 37, 38].

Atrial fibrillation (AF) was more frequent in subjects with PRESYF than in those with DESYF but the difference was not statistically significant: overall AF frequency was elevated (over $1 / 3$ of all the patients) and advanced age of our population has probably contributed to attenuate the differences of the two groups taking into account that AF is an age dependent phenomenon [39].

Hypertensive crisis and arrhythmia more frequently induced hospital admission in PRESYF HF than in DESYF HF subjects.

Length of in hospital staying was similar in the two groups but the severity of symptoms at discharge was different: 23 patients with PRESYF-HF and 74 with DESYF-HF were in NYHA class III-IV (21\% vs 29\%; OR 0,5 CI 95\% 0,3-0,89). This could underline that DESYF HF patients are more serious or that they improve slower. In-hospital deaths were 3 in the group PRESYF and 9 in the group DESYF ((2,6\% vs $4 \%$; ns).

The Brain natriuretic peptide (BNP) and N-terminal-probrain natriuretic peptide (NT- proBNP) data are numerically limited and therefore not suitable for statistic definition; nevertheless, BNP and NTproBNP values are lower in the PRES YF HF patients in comparison to those with DESYF HF. Since such markers are powerful predictors of new cardiovascular events $[40,41]$, it is probable that PRESYF-HF patients may have a better prognosis [32].

In conclusion, our data suggest that about one third of patients admitted for HF has a PRESYF. This result comes from a cohort very similar to "real world" of HF patients and that we have studied according to accurate diagnostic criteria (echocardiogram performed within 72 hours from the admission and LVEF $\geq 50 \%$ ). Patients with $\mathrm{HF}$ and PRESYF are different compared to those with DESYF. Particularly, they are older, primarily female, obese and with arterial hypertension. A correct identification of this form of HF may be important in clinical practice for more targeted therapeutic options and for prognostic implications.

\section{Riassunto}

Premesse. Vi è incertezza sulla prevalenza $e$ sulle caratteristiche cliniche dello scompenso cardiaco $(H F)$ con funzione sistolica conservata (PRESYF).

Scopo del lavoro. Analizzare la prevalenza e le caratteristiche cliniche di pazienti con PRESYF in una popolazione non selezionata di pazienti ricoverati consecutivamente per HF.

Metodi. La popolazione era composta da 338 pazienti ricoverati consecutivamente per $H F$ in 24 reparti di Medicina Interna della Toscana, senza nessuna esclusione. In tutti i pazienti fu eseguito un ecocardiogramma con misura della FEVS entro 72 ore dal ricovero. Furono considerati pazienti con PRESYF quelli con FEVS $\geq 50 \%$.

Risultati. I pazienti con PRESYF erano 112 (33,1\%), quelli con funzione VS depressa (DESYF) 226 (66,9\%). Nel gruppo PRESYF erano prevalenti sesso femminile, ipertensione arteriosa, elevato BMI, ed età avanzata.

Conclusioni. Circa un terzo dei pazienti ricoverati per HF appartengono al gruppo PRESYF $e$ possiedono differenti caratteristiche cliniche rispetto al gruppo DESYF. Una corretta identificazione di questa forma di HF è importante nella pratica clinica per un più appropriato indirizzo terapeutico $e$ per una migliore caratterizzazione prognostica.

\section{References}

1. Hogg K, Swedberg K, McMurray J. Heart failure with preserved left ventricular systolic function: epidemiology, clinical characteristics, and prognosis. J Am Coll Cardiol 2004; 43: 317-27.

2. Owan TE, Hodge DO, Herges RM, et al. Trends in prevalence and outcome of heart failure with preserved ejection fraction. N Engl J Med 2006; 355: 251-9.

3. Hildebrandt P. Systolic and Nonsystolic Heart Failure: Equally Serious Threats JAMA 2006; 296: 2259-2260.

4. Grossman W. Defining diastolic dysfunction. Circulation 2000; 101: 2020-2021.

5. Mandinov L, Eberli FR, Seiler C, Hess OM. Diastolic heart failure. Cardiovasc Res 2000; 45: 813-825.

6. Quinones M Á. Assessment of diastolic function. Prog Cardiovasc Dis 2005; 47: 340-355.

7. Maurer M S, Spevack D, Burkhoff D, Kronzon I: Diastolic dysfinction. Can it be diagnosed by Doppler Echocardiography? JACC 2004; 19: 1543-1549.

8. Mottram PM, Marwick TH: Assessment of diastolic function: what the general cardiologist needs to know. Heart 2005; 91: 681-695.

9. Petrie MCS, Hoggs K, Caruana L, Mc Murray JJV. Poor concordance of commonly used echocardiographic measures of left ventricular diastolic function in patients with suspected heart failure but preserved systolic function: Is there to reliable echocardiographic measure of diastolic dysfunction? Heart 2004; 90: 511-517.

10. Malki Q, Sharma ND, Afzal A, et al. Clinical presentation, hospital length of stay, anreadmission rate in patients with heart failure with preserved and decreased left ventricular ejection fraction: is it really a disorder of diastolic function? Circulation 2003; 107: 656-8.

11. Thomas M, Fox KF, Coats AJ, Sutton GC. The epidemiological enigma of heart failure with preserved systolic function. Eur J Heart Failure 2004; 6: 125-136.

12. Vasan RS, Larson MG, Benjamin EJ, Evans JC, Reiss CK, Levy D. Congestive heart failure in subjects with 
normal reduced left ventricular ejection fraction: prevalence and mortality in a population-based cohort. $J \mathrm{Am}$ Coll Cardiol 1999; 33: 1948-1955.

13. Philbin EF, Rocco TA Jr, Lindenmuth NW, et al. Systolic versus diastolic heart failure in community practice: clinical features, outcomes, and the use of angiotensin - converting enzyme inhibitors. Am J Med 2000; 109: 605-13.

14. Yturralde RF, Gaasch WH. Diagnostic criteria for diastolic heart failure. Prog Cardiovasc Dis 2005; 47: 314-319.

15. Bursi F, Weston AS, Redfield MM, et al. Systolic and Diastolic Heart Failure in the Community. JAMA 2006; 296: 2209-2216.

16. Vasan RSS, Levy D: Defining diastolic heart failure. A call for standardized diagnostic criteria. Circulation 2000; 101: 2118-2121.

17. Gandhi SK, Powers JC, Nomeir Á, et al. The pathogenesis acute of pulmonary edema associated with hypertension. N Engl J Med 2001; 344: 17-22.

18. Senni M, Tribouilloy C M, Rodeheffer R J, et al. Congestive Heart Failure in the Community: a Study of All Incident Cases in Olmsted County, Minnesota, in 1991. Circulation 1998; 98: 2282-2289.

19. ESC Guidelines for the diagnosis and treatment of Chronic Heart Failure: full text (update 2005). The Task Force for the diagnosis and treatment of CHF of the European Society of Cardiology. www. escardio.org/knowledge/guidelines

20. Feigenbaum H. Echocardiographic evaluation of cardiac chambers. In Echocardiography. 5th ed. Philadelphia: Lea and Febiger, 1994: 134-180.

21. Hedberg P, Lonnberg I, Jonason T, et al. Left ventricular systolic dysfunction in 75-year-old mens and women; a population-based study. Eur Heart J 2001; 22: 676-683.

22. Kitzman DWs, Gardin JM, Gottdiener JS, et al. Importance of heart failure with preserved systolic function in patients $=$ or $>65$ years of age. CHS Research Group. Cardiovascular Health Study. Am J Cardiol 2001; 87: 413-9.

23. Ceia F, Fonseca C, Mud T, et al. Prevalence of chronic heart failure in Southwestern Europe: The EPIC Study. Eur J Heart Fail 2002; 4: 531-9.

24. Devereux RB, Roman MJ, Liu JE, et al. Congestive heart failure despite normal left ventricular systolic function in to population-based sample: the Strong Heart Study. Am J Cardiol 2000; 86: 1090-6.

25. Masoudi A, Havranek EP, Smith G, et al. Gender, age, and heart failure with preserved left ventricular systolic function. J Am Coll Cardiol 2003; 41: 217-23.

26. Klapholz MS, Maurer M, Lowe Á M, et al. Hospitalization for Heart Failure in the Presence of to Normal Left Ventricular Ejection Fraction Results of the New York Heart Failure Registry. J Am Coll Cardiol 2004; 43; 1432-1438.

27. Cleland JGF, for the Study Group on Diagnosis of the Working Group on Heart Failureof the European Society of Cardiology. The EuroHeart Failure survey programme - a survey on the quality of care among patients with heart failure in Europe. Part 1. Patients characteristics and diagnosis. Eur Heart J 2003; 24: 442-63.

28. Berry C, Hogg K, Norrie J, Stevenson K, Brett M, Mc Murray J. Heart failure with preserved left ventricular systolic function: to hospital cohort study. Heart 2005; 91: 907-913.

29. Cohen-Solal Á, Desnos M, Delahaye F, Emeriau J P, Hanania $G$ for the Myocardiopathy and Heart Failure Working Group of the French Society of Cardiology, the National College of General Hospital Cardiologists and the French Geriatrics Society. A national survey of heart failure in French hospitals. Eur Heart J 2000; 21: 763-769.

30. Varela-Roman Á, Grigorian L, Barge E, Bassante P, de la Pena M G, Gonzalez-Juanatey JR. Heart failure in patients with preserved and deteriorated left ventricular ejection fraction. Heart 2005; 91: 489-494.
31. Macin S M, Perna N D R, Cimbaro Canella J P, et al. Differences in Clinical Profile and Outcome in Patients With Decompensated Heart Failure and Systolic Dysfunction or Preserved Systolic Function. Rev Esp Cardiol 2004; 57: 45-52.

32. Smith G L, Masoudi F Á., Vaccarino V, Radford M J, Krumholz H M. Outcomes in heart failure patients with preserved ejection fraction. Mortality, readmission, and functional decline. J Am Coll Cardiol 2003; 41: 1510-1518.

33. Bellotti P, Minds LP, Acquarone N, et al. Specialty-related differences in the epidemiology, clinical profile, management and outcome of patients hospitalized for heart failure. THE OSCUR study. Eur Heart J 2001; 22: 596-604.

34. Lenarda Á, Scherillo M, Maggioni AP, et al. Current presentation and management of heart failure in cardiology and internal medicines hospital units: a tale of two worlds - the TEMISTOCLE study. Am Heart J 2003; 146(4): E12S.

35. Fonarow GC for the ADHERE Scientific Advisory Committee. The Acute Decompensated Heart Failure National Registry (ADHERE): opportunities to improve care of patients hospitalized with acute decompensated heart failure. Rev Cardiovasc Med 2003; 4(suppl 7): 21-30.

36. Adams KF Jr, Fonarow GC, for the ADHERE Scientific Advisory Committee and Investigators. Characteristics and outcomes of patients hospitalized for heart failure in the United States: Rationale, design and preliminary observations from the first 100000 case in the The Acute Decompensated Heart Failure National Registry (ADHERE). Am Heart J 2005; 149: 209-216.

37. Ahmed Á, Roseman JM, Duxbury AS, Allman RM, Delong JF. Correlates and outcomes of preserved left ventricular systolic function among older adults hospitalized with heart failure. Am Heart J. 2002; 144(2): 365-72.

38. Ansari M, Alexander M, Tutar Á, Massie BM. Incident cases of heart failure in to community cohort: importance and outcomes of patients with preserved systolic function. Am Heart J 2003; 146(1): 115-20.

39. Heeringa J, Van Der Kuip DAM, Hofman A, et al. Prevalence, incidence and lifetime risk of atrial fibrillation: the Rotterdam study. Eur Heart J 2006; 27: 949-953.

40. Logeart D, Thabut G, Jourdain P, et al. Predischarge Btype natriuretc peptide assay for identifying patients at high risk of re-admission after decompensated heart failure. J Am Coll Cardiol 2004; 43: 635-641.

41. Verdiani V, Nozzoli C, Bacci F, et al. Pre-discharge Btype natriuretic peptide predicts early recurrence of decompensated heart failure in patients admitted to a general medical unit. Eur J Heart Fail 2005; 7: 566-571.

\section{Appendix}

\section{Partecipating centers}

Abbadia San Salvatore (R. Castro), Arezzo (C. Pedace, M. Bernardini), Barga (G. Rinaldi), Bibbiena (E. Santoro, G. Parca), Careggi Firenze (C. Nozzoli, V. Verdiani, MS Rutili), Castel del Piano (P. Corradini), Cecina (GF Landini), Empoli (G. Lombardo, A. Dei), Fivizzano (M. Cozzalupi, C. Gigli), Grosseto (M. Cipriani, M. Alessandri), Livorno (C. Bartolomei, C. Carnesecchi), Lucca (Nardini A, MC Andreucci, A. Tucci), Montepulciano (P. Biagi, L. Abate, S. Bocchini), Massa Marittima (A Brancato), Pescia (R. Laureano, G. Panigada), Piombino (A. Testa), Pisa (C. Passaglia, GC Tintori), Pistoia 1 (G. Pettinà), Pistoia 2 (G. Seghieri, F. Cipollini), Pitigliano (M. Manini), Poggibonsi (W. Boddi, A. Suardi), Portoferraio (D. Caniggia), S. Marcello Pistoiese (E. Silvestrini), Volterra (R. Capiferri, G. Vagheggini). 